\title{
PERAN BANK SYARIAH DALAM MENGURANGI KEMISKINAN
}

\author{
Abdul Hamid dan Aris \\ Sekolah Tinggi Agama Islam Negeri (STAIN) Parepare \\ Email: abdulhamid@stainparepare.ac.id \\ aris@stainparepare.ac.id
}

\begin{abstract}
This paper will see the Islamic Bank as an Islamic financial institution in order to participate in improving the welfare of all communities. Islamic banks have different purposes than conventional banks, Islamic banks as syariah-based banks and morals have a goal not only to achieve profit but also have social and spiritual goals (maqhasid shariah). Therefore the preparation of Sharia Bank business plan must be based on sustainable business principles and based on worldly balance with the creation of prosperity (maslahat) towards the achievement of eternal victory (falah).
\end{abstract}

\begin{abstract}
Abstrak: Tulisan ini akan melihat Bank Syariah sebagai lembaga keuangan Islam dalam rangka ikut berperan dalam meningkatkan kesejahteraan semua masyarakat. Bank syariah memiliki tujuan yang berbeda dengan bank konvensional, bank syariah sebagai bank yang berlandaskan syariah dan moral memiliki tujuan bukan hanya mencapai keuntungan semata tetapi juga memiliki tujuan sosial dan spiritual (maqhasid syariah). Oleh karenanya penyusunan rencana bisnis Bank Syariah harus dilandasi dengan prinsip bisnis yang berkelanjutan dan mendasarkan pada keseimbangan duniawi dengan terciptanya kesejahteraan (maslahat) menuju tercapainya kemenangan yang abadi (falah).
\end{abstract}

Kata Kunci: Ekonomi, Kemiskinan, dan Bank Syariah

\section{PENDAHULUAN}

Kesenjangan ekonomi antar wilayah merupakan fenomena global yang sering terjadi di negara baik di negara berkembang maupun di negara maju sekalipun. Hal ini terjadi diakibatkan karena para pengambil kebijakan baik dipemerintahan maupun para pelaku bisnis hanya berbasis pada pemikiran konvensional yang bertumpu hanya pada peningkatan pertumbuhan ekonomi, karena itu, mereka tidak menganjurkan kebijakan pembagian yang adil sebelum kemajuan dicapai dalam bentuknya yang sangat pesat. Hal inilah yang membawa perekonomian suatu negara mengalami keterpurukan ekonomi yang berdampak pada tidak meratanya penghasilan masyarakat yang memicu munculnya kemiskinan dan kesenjangan sosial yang meluas yang tidak disadari oleh para pengambil kebijakan karena terdoktrin dengan pemahaman kapitalis.

Berdasarkan hal tersebut dapat dipastikan bahwa kesenjangan sosial 
merupakan sebuah problematika kemanusiaan yang mendunia dan hingga kini masih menjadi isu sentral di belahan bumi manapun. Selain bersifat laten dan aktual, kemiskinan adalah penyakit sosial ekonomi yang tidak hanya dialami oleh negara-negara berkembang melainkan juga negara maju seperti Inggris dan Amerika Serikat. ${ }^{1}$

Oleh karena itu aspek pemerataan dan kesempatan harus menjadi perhatian bagi semua pihak dalam dalam rangka terciptanya stabilisasi ekonomi yang tentunya dimulai dari ekonomi lapisan bawah. Stabilisasi yang dimaksud bahwa dalam perekonomian suatu negara harus ada standar ukur yang menjadi acuan untuk melihat pergerakan stabilisasi ekonomi yang merata yaitu indeks peningkatan atau pertumbuhan pemerataan, bukanlah diukur dengan peningkatan pendapatan perkapita masyarakat.

Perhatian ini timbul karena ada kecenderungan bahwa kebijakan pembangunan yang dirancang untuk meningkatkan pertumbuhan ekonomi justru memperburuk kondisi kesenjangan ekonomi antar wilayah dalam suatu negara. Fenomena kesenjangan sosial yang terjadi di masyarakat adalah aktual dan riel dan semakin memprihatinkan sebagai akibat kebijakan ekonomi pemerintah yang seringkali kecolongan yang berdampak pada pertumbuhan ekonomi yang meningkat tajam, tetapi dibarengi dengan ketimpangan ekonomi dan kesenjangan sosial yang memprihatinkan, maka dibutuhkan perjuangan dan keberanian dalam mengurai baik pemikiran maupun dalam aksi nyata dalam rangka meningkatkan taraf hidup rakyat banyak guna mendorong terwujudnya nilai keadilan terhadap manusia dan lingkungan alam, sebagaimana shariate enterprise theory yaitu manusia adalah khalifatullah fil ardh yang membawa misi menciptakan dan mendistribusikan kesejahteraan bagi seluruh manusia dan alam. ${ }^{2}$

Salah satu cara untuk keluar dari permasalahan tersebut dalam rangka meningkatkan taraf hidup dan kesejahteraan yang menyeluruh pada lapisan masyarakat maka diperlukan pengetahuan khusus yaitu pengetahuan ekonomi yang berbasis nilai syariah dimana setiap manusia selalu menginginkan kehidupannya di dunia ini dalam keadaan bahagia, baik secara material maupun spiritual, individual maupun sosial.

Kebahagiaan multidimensi ini sangat sulit diraih karena keterbatasan kemampuan manusia dalam memahami sumber daya yang bisa digunakan serta lembaga keuangan yaitu bank syariah sebagai ujung tombak dalam rangka memperlancar mekanisme ekonomi di sektor riil sebagai mediator penyimpanan dana dan atau pembiayaan kegiatan usaha, atau kegiatan lainnya juga masih kurang memahami hakikat dan tujuannya. Hal ini disebabkan karena masih dalam tahap penyempurnaan akademik.

Bank syariah memiliki tujuan yang berbeda dengan bank konvensional, bank syariah sebagai bank yang berlandaskan syariah dan moral memiliki tujuan bukan 
hanya mencapai keuntungan semata tetapi juga memiliki tujuan sosial dan spiritual (maqhasid syariah). Selanjutnya maqhasid syariah atau tujuan syariah bertujuan untuk mewujudkan kemaslahatan bagi ummat. Oleh karenanya penyusunan rencana bisnis Bank Syariah harus dilandasi dengan prinsip bisnis yang berkelanjutan dan mendasarkan pada keseimbangan duniawi dengan terciptanya kesejahteraan (maslahat) menuju tercapainya kemenangan yang abadi ukhrawi (falah)

\section{PEMBAHASAN}

Tujuan pembangunan ekonomi setiap negara adalah tercapainya pembangunan ekonomi yang adil dan merata. Pembangunan ekonomi adalah sebuah usaha untuk meningkatkan taraf hidup suatu bangsa yang diukur melalui tinggi rendahnya pendapatan riil per kapita. Pembangunan ekonomi merupakan suatu proses multidimensi yang melibatkanperubahan-perubahan besar dalam struktur sosial, sikap masyarakat, dan kelembagaan nasional, seperti halnya percepatan pertumbuhan ekonomi, pengurangan ketidakmerataan dan pemeberantasan kemiskinan absolut. $^{3}$

Kemiskinan diartikan sebagai suatu keadaan di mana seseorang tidak sanggup memilihara dirinya sendiri sesuai dengan taraf kehidupan kelompok dan juga tidak mampu memanfaatkan tenaga mental maupun fisik dalam kelompok tersebut. Dan dapat diartikan juga sebagai Kesenjangan ekonomi atau ketimpangan dalam distribusi pendapatan antara kelompok masyarakat berpendapatan tinggi dan kelompok masyarakat berpendapatan rendah serta tingkat kemiskinan atau jumlah orang yang berada di bawah garis kemiskinan (poverty line) merupakan dua masalah besar di banyak negara-negara berkembang tidak terkecuali di Indonesia. Pemberdayaan merupakan salah satu kegiatan yang dilakukan untuk menekan angka kemiskinan agar tercapai tujuan pembagunaanmenurut Chambers menggambarkan kemiskinan, terutama di pedesaan mempunyai lima karakteristik yang saling terkait: kemiskinan material, kelemahan fisik, keterkucilan dan keterpencilan, kerentanan, dan ketidakberdayaan. ${ }^{4}$

Kemiskinan yang terus berkelanjutan tentu akan memberikan dampak sosial yang tidak dikehendaki masyarakat. Gejala-gejala yang wajar dalam masyarakat seperti norma-norma, kelompok sosial lapisan masyarakat, lembaga kemasyarakatan, proses sosial, perubahan sosial dan kebudayaan serta perwujudannya akan berubah menjadi gejala patologis, hal ini disebabkan adanya unsur-unsur masyarakat tidak dapat berfungsi sehingga menyebabkan kekecewaan dan penderitaan.

Paradigma tricle down effect, yang dikembangkan kapitalisme dan pernah diterapkan di Indonesia selama rezim orde baru, bertentangan dengan konsep keadilan ekonomi menurut Islam. Sistem ekonomi kapitalis dicirikan oleh menonjolnya peran perusahaan swasta (private ownership) dengan motivasi 
mencari keuntungan maksimum, harga pasar akan mengatur alokasi sumberdaya, dan efisiensi. Namun sistem ini selalu gagal dalam membuat pertumbuhan dan pemerataan berjalan dengan seiring. ${ }^{5}$

Sedangkan beberapa ciri budaya kemiskinan antara lain seperti: fatalisme, rendahnya tingkat aspirasi, rendahanya kemauan mengejar sasaran, kurang melihat kemajuan pribadi, perasaan ketidakberdayaan / ketidakmampuan, perasaan untuk selalau gagal, perasaaan menilai diri sendiri negatif, pilihan sebagai posisi pekerja kasar, tingkat kompronis yang menyedihkan. ${ }^{6}$

\section{Penanggulangan Kemiskinan}

Persoalan kemiskinan dan kesenjangan sosial masih menjadi masalah besar di negara Indonesia terutama didaerah pedesaan. Persoalan kemiskinan dan kesenjangan sosial dapat menjadi konflik untuk itu harus mencari alternatif Penanggulangan kemiskinan. Kemiskinan sebagai suatu kondisi tidak terpenuhinya kebutuhan dasar (esensial) individu sebagai manusia ${ }^{7}$. Salah satu upaya dalam penanggulangan kemiskinan adalah dengan pemberdayaan, misalnya pemberdayaan lingkungan dan pembedayaan kewirausahaan. Pemberdayaan adalah suatu proses yang mengembangkan dan memperkuat kemampuan masyarakat untuk terus terlibat dalam proses pembangunan yang secara dinamis sehingga masyarakat dapat menyelesaikan masalah yang dihadapi serta dapat mengambil keputusan. Pemberdayaan merupakan program komprehensif dan terpadu dalam rangka peningkatan mutu Sumber Daya Manusia, human capital, yang sekaligus diarahkan untuk mencapai Millenium .kemiskinan dan peningkatan mutu manusia yang berbudaya dan demokratis.

2. Strategi dalam penanggulangan kemiskinan, antara lain ${ }^{8}$ :

Strategi untuk mengatasi krisis kemiskinan tidak dapat lagi dilihat dari satu dimensi saja (pendekatan ekonomi), tetapi memerlukan diagnosa yang lengkap dan menyeluruh (sistemik) terhadap semua aspek yang menyebabkan kemiskinan secara lokal. Untuk mencapai sasaran penurunan angka kemiskinan KPK menetapkan strategi pemberdayaan masyarakat melalui 2 (dua) cara yaitu

a. Mengurangi beban pengeluaran konsumsi kelompok miskin

b. Meningkatkan produktivitas masyarakat miskin untuk meningkatkan pendapatannya.

Peningkatan produktivitas dilakukan melalui pengembangan dan pemberdayaan usaha masyarakat terutama Usaha Mikro, Kecil dan Menengah yang meliputi penajaman program, pendanaan, dan pendampingan. Pendampingan yang dimaksud di sini adalah program penyiapan, pemihakan dan perlindungan untuk meningkatkan kapasitas sumberdaya masyarakat dan kelembagaannya sebagai pemanfaat program agar pendanaan yang disalurkan dapat terserap dan termanfaatkan dengan baik. Dan memperbanyak jumlah UKM simpan pinjam di daerah yang berperan 
sebagai sarana yang dapat digunakan masyarakat yang dapat membantu permodalah usaha-usaha masyarakat selain itu, diharapkan dapat memenuhi kebutuhan sehari-hari masyarakat. Dengan demikian aktivitas dan produktivitas ekonomi masyarakat akan meningkat dan bertumbuh.

Namun hal tersebut diatas tidaklah memberikan dampak yang signifikan dan nyata yang dapat mendongkrak ekonomi pedesaan atau masyarakat lapis bawah untuk keluar dari lingkaran yang mencekik di pusaran kapitalis. Oleh karena itu dibutuhkan suatu konsep pemikiran yang memberikan solusi untuk keluar dari permaslahan tersebut diatas

\section{B. Teologi Ekonomi: Solusi Ekonomi Masa Depan}

Membangun ekonomi rabbaniyah bagi bangsa Indonesia tidaklah sulit karena banyaknya potensi atau daya dukung yang bisa dikembangkan. Daya dukung itu sekaligus merupakan kekayaan dan modal dasar yang sangat kondusif untuk digali antara lain kekayaan spritual yang bersumber dari ajaran agama. $^{9}$

Indonesia yang mayoritas penduduknya adalah muslim menjadikan potensi yang besar serta pemeluk agama yang pluralis sehingga pelaksanaan ekonomi berkesadaran teologis menjadi modal dasar dalam mengembangkan ekonomi syariah yang bersumber dari ajaran Alquran dan Hadis dengan sebuah harapan ekonomi indonesia akan bertumbuh dan akan berimplikasi pada menurunnya tingkat kemiskinan yang terus menghantui.

Konsep pertumbuhan ekonomi yang dibangun dalam Islam berbeda dengan konsep pertumbuhan ekonomi kepitalisme yang selalu menggunakan indikator PDB (Produk Dosmetik Bruto) dan perkapita. Dalam Islam, pertumbuhan harus seiring dengan pemerataan. Tujuan kegiatan ekonomi, bukanlah meningkatkan pertumbuhan sebagaimana dalam konsep ekonomi kapitalisme. Tujuan ekonomi Islam lebih memprioritaskan pemerataan sehingga jumlah masyarakat miskin dan pengangguran berkurang. Karena itu, Islam menekankan keseimbangan antara petumbuhan dan pemerataan. Pertumbuhan bukan menjadi tujuan utama, kecuali dibarengi dengan pemerataan. Dalam konsep Islam, pertumbuhan dan pemerataan merupakan dua sisi dari sebuah entitas yang tak terpisahkan, karena itu keduanya tak boleh dipisahkan.

Islam telah menjelaskan prinsipprinsip dasar ekonominya, prinsip tauhid,, khilafah dan adala' seharusnya dijadikan patokan dasar oleh semua lembaga keuangan baik konven maupun syariah dalam rangka meningkatkan dan menggairahkan aktivitas investasi baik makro maupin mikro, bahkan banyak sekali istilah-istilah bisnis yang dipakai dalam bahasa Quran dan Hadits seperti kredit (alqard), jual beli (albae), gadai (arrahn) dan lainnya. Adapun prinsipprinsip dasar ekonomi Syariat yang selama ini kita kenal melalui Bank Syariah adalah nilai-nilai etika dan 
norma ekonomi yang universal dan komprehensif. Keuniversalan itu sengaja diberikan pada umat untuk memberikan kesempatan padanya agar berinovasi (ijtihad) dan berkreasi (jihad) dalam mengatur sistem ekonominya dengan syarat tidak keluar dari kerangka umumnya. Dengan demikian sistem ekonomi Islam akan senantiasa valid dan cocok untuk setiap perubahan waktu dan perbedaan tempat dan mampu memerankan fungsinya sebagai khalifah di muka bumi ini. Norma-norma tadi adalah merupakan prinsip-prinsip dasar Bank Syariah, Dengan mengamati aturan ekonomi yang ada dalam Quran dan Hadits, jelaslah bahwa Islam benar-benar telah mengatur system ekonomi dengan teliti dan jelas melalui nilai-nilainya yang universal, yaitu bahwa setiap transaksi ekonomi (muamalat) harus didasarkan pada asas kejujuran, keadilan, toleransi dan suka sama suka, baik dalam perdagangan, kerjasama (sharing) ataupun semua aspek ekonomi. Indikasinya bisa dilihat dari dibolehkannya sistem barter (materi dan manfaat), baik melalui jual beli, sewa menyewa, penggadaian, kerja sama dan lainnya.

Islam juga telah memberikan kebebasan yang seluas-luasnya dalam melakukan transaksi ekonomi (selama tidak melanggar nilai-nilai universal Islam) bahkan menyuruh umatnya untuk terus dinamis dalam menciptakan kemudahan-kemudahan transaksi melalui instrumen-instrumennya agar selalu update dan valid dengan perubahan waktu dan perbedaan tempat.
Indikasinya nampak pada tidak ada pengkhususan instrumen tertentu atau pembatasan pada instrumen tertentu. Apa yang telah diterapkan Rasulullah dan para sahabatnya pada jaman itu adalah hanya kecocokan jaman dan pengenalan mereka pada instrumen dan produk tersebut, dimana hanya instrumen/ produk itulah yang dikenal mereka dan dipakai pada saat itu. Artinya tidak ada keharusan bagi generasi-generasi berikutnya untuk melaksanakan instrumen dan produk yang pernah dipakai mereka selama nilai-nilai universalnya tetap dipertahankan. Menurut Yusuf Qardhawi nilai moral harus merasuk kedalam aktivitas produksi, komsumsi, sirkulasi dan distribusi.

\section{Bank Syariah dalam Mengurai Kesenjangan}

Dewasa ini atmosfer syariah semakin digemari masyarakat Indonesia. Namun sayangnya esensi syariah tampaknya belum terintegrasi di dalam akad-akad transaksi syariah. Beberapa penelitian mengungkapkan bahwa terdapat beberapa faktor yang memicunya. Hasil penelitian menunjukkan bahwa terdapat dua faktor yang memicu mengapa perbankan syariah masih diidentikkan dengan perbankan konvensional, yaitu :

1. Faktor standar.

Standar yang berupa PSAK syariah dinilai belum sepenuhnya syariah dan implementatif

2. Terkait dengan pemahaman SDM perbankan syariah tentang syariah. 
Berdasarkan hal tersebut, sumber daya manusia sebagai faktor utama berkembangnya institusi ekonomi berbasiskan hukum Islam, masih banyak yang belum memahami dan mengenal perekonomian yang berbasis syariah secara menyeluruh. Walaupun di sisi lain, MUI sudah mengeluarkan fatwa haram atas bunga bank yang menjadi acuan bagi umat Islam di Indonesia agar memilih institusi keuangan yang tidak menerapkan sistem bunga. Perjalanan waktu menunjukkan, bahwa ekonomi syariah bisa menjadi pilihan untuk mengatasi masalah umat, yang saat ini masih mengalami krisis kepercayaan.

$\begin{array}{ccr}\text { Untuk } & \text { lebih } & \text { meningkatkan } \\ \text { pemahaman } & \text { dan } & \text { kepercayaan } \\ \text { masyarakat } & \text { mengenai } & \text { prinsip-prinsip }\end{array}$ dasar ekonomi syariah, harus dibarengi dengan sosialisasi secara total melalui intervensi pemerintah melalui kebijakan pendidikan dan dukungan politik sejak dini dengan memberikan pondasi pengetahuan berbasis ekonomi Islam sejak duduk dibangku sekolah menengah tanpa harus menunggu mereka menempuh pada pendidikan tinggi.

Dengan kebijakan pendidikan tersebut, pemahaman tentang ekonomi Islam yang tidak hanya terbatas pada level akademik perguruan tinggi tetapi sudah menjadi kesatuan atau bagian dengan masyarakat keseluruhan, sehingga dengan demikian pemahaman ekonomi Islam dilapangan tidak lagi terbentur hanya pada wacana pemikiran dilingkungan perguruan tinggi dan lembaga keuangan Islam tetapi penerapannya akan lebih mudah diimplementasikan karena sosialisasinya sudah terlaksana pada jenjang pendidikan tingkat menengah sehingga merata di lapisan masyarakat.

Dan bukan tidak mungkin akan terjadi perubahan yang luar biasa, dimana nilai-nilai kejujuran, keadilan, transparansi dan seluruh aspek spiritual menjiwai semua kegiatan bisnis/transaksi ekonomi masyarakat yang pada akhirnya melahirkan kesadaran kolektif masyarakat muslim.

Sebagai penduduk mayoritas muslim, seyogyanya lembaga keuangan berbasis syariah harus menjadi penggerak roda perekonomian dan lebih berperan dan diperankan oleh negara sebagai mediasi dana dari yang kaya ke yang miskin sekaligus media dakwah dalam memperjuangkan bisnis yang berkeadilan sebagai sebuah sumber keuangan berkelanjutan dalam meningkatkan pendapatan yang pada akhirnya mengurangi kesenjangan sosial.

Oleh karena itu bank syariah sebagai sebuah lembaga keuangan islam harus mengambil peran dalam mengurangi kemiskinan serta memperjuangkan nilai nilai bisnis berkeadilan dan sekaligus berbenah dengan meningkatkan pemahaman SDM khususnya aturan hukum Islam tentang ekonomi Islam (muamalah), dengan demikian para pelaku perbankan syariah tidak dikwatirkan lagi mengeksploitasi penafsiran fatwa yang telah di fatwakan sebagaimana sekarang yang masih banyak mengeksploitasi penafsiran DSN sesuai dengan argumentasinya masing masing yang tidak berdasar, akibatnya 
kepercayaan masyarakat akan keberadaannya akan memberikan dampak negatif bagi Bank Syariah untuk tumbuh berkembang bersama umat.

Berdasarkan hal diatas, bank syariah perlu lebih dekat dengan umat, dengan masyarakat terutama masyarakat yang berekonomi kelas bawah. Bank syariah tidak hanya mengejar materi semata dan margin yang besar, namun membawa umat dalam kepercayaan terhadapnya. Dalam hal ini masyarakat akan memberikan penilaian positif sebagai inspirasi untuk bank syariah agar tumbuh berkembang bersama umat. ${ }^{10}$ Dalam rangka mengentaskan kemiskinan dan kesenjangan sosial. Bank syariah sebagai derivasi dari imlpementasi dari maqasid syariah diharapkan menjadi sponsor dan perpanjangan tangan para ulama dalam mamasyarakatkan ekonomi ilahiyah baik dalam lembaga pendidikan formal setara dengan pendidikan menengah maupun para pelaku bisnis khususnya pelaku usaha mikro sebagai basis fundamen ekonomi nasional.

Keprihatinan masyarakat terhadap perilaku dari semua elemen bank syariah baik praktisi perbankan syariah maupun ulama dikarenakan secara tidak sadar telah menjadi penikmat konvensional karena sebuah sistem dan pemahaman yang sudah membudaya. Hal tersebut karena bunga sebagai kategori riba masih dalam wilayah perdebatan para fuqaha. Keprihatinan ini perlu diungkap sebab perbedaan pendapat para ulama tentang bunga masih diperbolehkan dengan alasan kemaslahatan. Oleh karena itu ketegasan terhadap komitmen bank syariah harus jelas.

Alasan yang selalu dijadikan justifikasi oleh semua lapisan masyarakat adalah sepanjang tidak melanggar syariah masih dibolehkan. Ini adalah suatu pernyaatan yang tidak rasional sebab bisa saja paham kapitalismepun juga ada yang sesuai dengan syariat Islam. Jika demikian halnya maka kapitalis konvensional tidak ubahnya adalah ekonomi Islam.

Oleh karena itu perbankan syariah sebagai derivasi dari ilmu ekonomi ilahiyah tidak boleh lepas dari dari dua permasalahan mendasar yaitu :

1. Permasalahan yang bersifat filosofis-konsepsional-paradigmatik dan merupakan tanggungjawab para ulama serta akademisi.

2. Permasalahan yang bersifat implementasi, operasional, emperik dan merupakan tanggungjawab praktisi ekonomi Muslim, manajer profesional dan para bankir.

Mengedepankan aspek pertama tanpa ada upaya implementatif akan menjadikan bank Islam sebatas uthopia belaka, sebaliknya mengedepankan aspek kedua tanpa dibangun terlebih dahulu landasan filosofisparadigmatiknya justru menjadikan bank Islam sebagai suatu bangun usaha ekonomi yang berdiri diatas puing puing ketidakpastian. ${ }^{11}$

Dari alasan tersebut diatas Dewan Syariah Nasional dan lembaga keuangan syariah harus bersinergi. Pihak perbankan syariah harus menyadari bahwa pasar potensil adalah masyarakat 
muslim yang mayoritas ekonominya adalah lapis bawah sehingga DSN sebagai lembaga otonom MUI yang menyandang predikat Ulama sebagai penyandang ahli agama yang meletakkan dasar pengembangan ekonomi yang berbasis Alquran dan Sunnah harus dilibatkan, perbankan di setiap wilayah harus mempedulikan keberadaan para ulama lokal sebagai corong dalam sosialisasi sementara perbankan syariah sebagai lembaga profesional harus berbenah khususnya pengembangan sumber daya manusia.

Di sisi lain, Bank syariah memang perlu menyusun strategi yang nyata untuk mencapai target yang ditetapkan tanpa mengesampingkan kepercayaan masyarakat. Salah satu strategi yang dilakukan bank syariah untuk mengentas kemiskinan adalah berupa pembinaan nasabah yang lebih menonjol sifat kebersamaan dari siklus usaha yang lengkap seperti program pembinaan pengusaha produsen, pembinaan pedagang perantara, pembinaan konsumen, pengembangan modal kerja dan pengembangan usaha bersama guna mengurangi tingkat kemiskinan.

Dalam mengurai kemiskinan, AlQuran menganjurkan banyak cara yang harus ditempuh, yang secara garis besar dapat dibagi pada tiga hal pokok :

1. Kewajiban terhadap setiap individ $\mathrm{u}$ tercermin dalam kewajiban bekerja dan berusaha. Kerja dan usaha merupakan cara pertama dan utama yang ditekankan oleh Kitab Suci AlQuran, karena hal inilah yang sejalan dengan naluri manusia, se kaligus juga merupakan kehormatan dan harga dirinya.

Dijadikan indah dalam (pandangan) manusia kesenangan kepada syahwat, berupa wanita (lawan seks), harta yang banyak dari jenis emas dan perak, kuda pilihan, binatang ternak, dan sawah ladang. Itulah kesenangan hidup duniawi. dan di sisi Allah tempat kecuali yang baik (QS Ali 'Imran: 14).

2. Kewajiban orang lain tercermin pada jaminan satu rump un keluarga, dan jaminan sosial dalam bentuk zakat dan sedekah wajib.

Sebelum menguraikan cara kedua ini, perlu terlebih dah ulu

digarisbawahi bahwa menggantun gkan penanggulangan problem kemiskinan semata-mata kepada sumbangan sukarela dan keinsafan pribadi, tidak dapat diandalkan. Teori ini telah dipraktekkan berabad-abad lamanya, namun hasilnya tidak pernah memuaskan.

Sementara orang sering kali tidak merasa bahwa mereka mempunyai tanggung jawab sosial , walaupun ia telah memiliki kelebihan harta kekayaan. Karena itu diperlukan adanya penetapan hak dan kewajiban aga $r$ tanggung jawab keadilan sosial dapat terlaksana dengan baik. 


\section{Kewajiban Pemerintah}

Pemerintah juga berkewajiban mencukupi setiap kebutuhan warga negara, melalui sumber-sumber dana yang sah. Yang terpenting di antaranya adalah pajak, baik dalam bentuk pajak perorangan, tanah, atau perdagangan, maupun pajak tambahan lainnya yang ditetapkan pemerintah bila sumbersumber tersebut di atas belum mencukupi. ${ }^{12}$

Dalam mengurangi tingkat kemiskinan, peran dan kebijakan pemerintah sangat dibutuhkan dengan mengoptimalkan dan memberdayakan lembaga keuangan syariah sebagai agen perubahan pola pikir masyarakat, Pola pikir yang dimaksud adalah memberikan pemahaman kepada para pelaku bisnis dan masyarakat pada umumnya tentang keberadaan dari ekonomi berkesadaran teologis. Pemerintah dalam hal ini memberikan kebijakan tentang fungsi dan tugas dan tujuan bank syariah tidak hanya sebagai profit orientasi berbasis islam tetapi juga bank syariah menjadi agen sosial di masyarkat dengan tugas membantu pemerintah dalam hal pengelolaan sumber sumber pemasukan ke negara dalam menanggulangi tingkat kemiskinan.

Salah satu diantaranya melalui pemberdayaan zakar profesi dengan menyalurkan dana kepada usaha kecil yang membutuhkan dana. Oleh karena itu menurut penulis segmentasi pasar utama dari keberadaan bank syariah adalah memberdayakan masyarakat kecil dalam meningkatkan produktivitas mereka dengan tidak melupakan pasar yang lebih besar dengan tujuan untuk mensosialisasikan ekonomi berkeadilan kepada segmen pasar yang lebih besar (pengusaha menengah atas).

Dalam perspektif manajemen perusahaan, bank syariah sebagai lembaga profesional tentu lebih berkompoten dalam hal pengelolaan dana. Oleh sebab itu pemerintah seharusnya memberikan wewenang kepada Bank Syariah dalam 'memberdayakan' Zakat, Infaq dan Shodaqoh (ZIS). sebagai lembaga pengumpul dan penyalur dana zakat. Pada kenyataannya ZIS di Bank Syariah hanya beberapa \% saja, sehingga dampaknya belum cukup besar. Seperti kita ketahui ZIS juga sangat berpengaruh terhadap kesejahteraan umat, namun penyalurannya juga perlu diperhatikan dengan baik.

Konsep yang kami bangun terhadap eksistensi bank syariah adalah pemerintah disetiap daerah harus melibatkan bank syariah sebagai lembaga yang mengelola pengumpul dan penyalur dana baik dana umum maupun dana zakat masyarakat yang ada disetiap wilayah/daerah sampai ke tingkat kecamatan dengan melibatkan unsur pemerintah dalam hal ini adalah pengelola baznas di setiap daerah sebagaimana keberadaan bank pembangunan daerah (bank Pemda)

Kajian filosopis, konsepsional, paradigmatik yang merupakan tanggungjawab para ulama serta akademisi terhadap eksistens bank syariah sangat bertolak belakang 
sebagaimana keberadaannya saat ini. Bank syariah seharusnya difungsikan sebagai lembaga keuangan negara yang berfungsi tidak hanya sebagai agen bagi masyarakat yang kelebihan dan kekurangan dana tetapi jauh lebih penting sebagai agen pembangunan mental berkesadaran ekonomi berkeadilan (ilahiya) yang akan melahirkan nilai nilai kejujuran dalam aktivitas ekonomi masyarakat.

Oleh karena itu sebagai lembaga keuangan syariah dilihat dari segi manajemen pengelolaan dana lebih profesional dibandingkan lembaga lainnya sehingga dana yang terkumpul maupun yang tersalur akan lebih terarah. Oleh karena itu paradigma pengelolaan dana ZIS harus berorientasi pada bisnis produktif untuk permodalan usaha kecil, sehingga masyarakat miskin dalam hal ini didalamnya adalah orang yang kurang modal perlu diberikan dengan harapan mampu menggerakkan roda ekonomi kelas bawah yang tentunya akan membawa sebuah perubahan sosial ke arah yang positif

Sejalan dengan hal tersebut diatas bank syariah harus membuka peluang berusaha atau bergerak yang lebih besar sehingga dapat melakukan usaha-usaha yang produktif serta menjadikan dirinya sebagai intermediary dengan pemerintah dalam rangka menjalankan program pemerintah yang beorientasi pada pemerataan kesejakteraan. Pembinaan dan pendampingan terhadap pelaku ekonomi harus menjadi perhatian sebagai isu strategis dan maqasid syariah sebagai instrumen nya, sebagaimana program pemerintah yaitu program PMPM yaitu masyarakat miskin diberdayakan dengan tujuan untuk meningkatkan kesejahteraan melalui pendampingan.

Berdasarkan hal tersebut bank syariah seyogyanya fokus pada pembinaan mitra atau nasabahnya dengan melibatkan ulama sehingga aktivitas perdagangan atau bisnis tidak lepas dari nilai nilai rabbaniyah dengan harapan terwujudnya pemerataan ekonomi, pengentasan kemiskinan dan mengurangi kesenjangan sosial. Program program bantuan yang selama ini berjalan pada masyarakat ekonomi kecil seperti program UKM, Koperasi, BMT tidak berbeda dengan konsep kapitalis sebagai derivasi daripada perusahaan besar sebagai mitra bisnis dan bahkan menjadi bapak angkat. Inilah penyebab utama program program tersebut tidak berkelanjutan dan bertumbuh sebagaimana harapan masyarakat, yang oleh penulis diistilahkan UKM kapitalis berbasis konvensional.

Oleh karena itu konsep dan tujuan bank Syariah disamping profit orientied yaitu untuk mendapatkan keutungan, namun dibalik keuntungan tersebut ada nilai nilai yang harus dikedepankan yaitu keadilan dan kejujuran yang melekat dalam rangka mencapai tujuannya yaitu kesejahteraan umat melalui cara-cara yang halal.(maqasid syari'ah) "Jadi, keberhasilan suatu bank syariah dapat dilihat jika berdampak pada meningkatnya kesejahteraan masyarakat pada lapisan mikro. Prinsip pokok Bank Syariah adalah sama-sama untung tapi 
juga sama-sama rugi. "Namun untuk itu, keduanya yakni antara nasabah dan Bank Syariah harus sama-sama jujur. Nah padahal sama-sama jujur ini yang kadang-kadang yang sulit dimplementasikan ${ }^{13}$.Oleh karena itu Bank syariah disamping sebagai finance intermediate dalam mendukung aktivitas ekonomi juga yang lebih penting adalah sebagai motivator pemberdayaan dalam rangka pemerataan penghasilan yaitu menyejahterakan umat dengan 'menggalakan' program-program secara berkesinambungan. Selain membantu permodalan dan pembiayaan, bank syariah juga sekaligus memberikan edukasi atau pencerdasan tentang bank syariah baik bagi pengusaha kalangan atas maupun kalangan menengah kebawah, sehingga keduanya akan memberikan andil dalam menciptakan kesadaran untuk pembangunan unit usaha kecil dengan tidak mengabaikan sektor makro. Dengan fokus pada pemerataan penghasilan idealnya bank syariah dengan berbagai produknya mengarahkan aktivitas bisnisnya pada level ekonomi lapis bawah, fasilitas produk yang dihasilkan diharapkan dapat menggerakan sektor riel khususnya UKM. Sebagai contoh : Produk salam. Sebagai negara agraris yang sangat berpotensi dalam bidang pertanian serta pelestarian sumber daya alam yang ada, maka seyogyanya pemanfaatan tersebut harus berorientasi pada produk tersebut. Salam dalam hal ini adalah salah satu produk bank syariah dengan sistem jual beli yang harga dibayar lebih dulu dan barang diserahkan kemudian (khusus hasil pertanian, peternakan atau perkebunan. Usaha ini tidak hanya menguntungkan bagi para pemodal atau shahibul maal, usaha ini juga mengangkat perekonomian masyarakat kecil atau masyarakat menengah kebawah.

Untuk dapat mengatasi hal ini perlu adanya kepercayaan, kejujuran dan rasa tanggungjawab yang tinggi antara bank syariah, pemodal (sahibul mal) dan pengelola (mudharib) sebagaimana dijelaskan diatas. Wapres Jusuf kalla mengungkapkan bahwa Kejujuran yang tinggi harus ada kalau benar-benar ingin sistem syariah, sama-sama untung tapi juga sama-sama kalau rugi. Oleh karena itu, keduanya yakni antara nasabah dan Bank Syariah harus sama-sama jujur. Sementara nilai nilai kejujuran kadangkadang yang sulit ditunaikan, Selain dari sisi pengembangan produk yang sudah ada dan peningkatan inovasi produk yang sedang dilakukan,

Komitmen Islam yang besar terhadap kejujuran dan tanggungjawab tidak lain adalah untuk mewujudkan maqashid syari'ah, yakni pemenuhan kebutuhan hidup manusia, terutama kebutuhan dasar (primer), seperti sandang, pangan, papan, pendidikan kesehatan. Sementara persaudaraan dan keadilan menuntut agar sumberdaya didistribusikan secara adil kepada seluruh rakyat melalui kebijakan yang adil dan instrumen zakat, infaq, sedekah, pajak, kharaj, jizyah, cukai ekspor-impor dalam rangka terciptanya pemerataan pendapatan yang diidam idamkan. 
Permasalahan mendasar yang dialami oleh rakyat kecil atau usaha kecil adalah masalah permodalan, manajemen usaha, akses pasar dan keterampilan dan wawasan yang terbatas. Oleh karena itu bank syariah harus komitmen menjalankan ekonomi syariah sebagai amanah ilahiyah yang harus dukung oleh semua pihak. Sebagai sebuah amanah bank syariah dalam implementasinya harus memberi bantuan pendampingan, bukan hanya permodalan tetapi bantuan manajemen, keterampilan dan wawasan teologis.

Prinsip dan hakekat bank syariah yang sebenarnya adalah sistem joint venture dalam ekonomi konvensional (kerja sama) dimana kedua belah pihak bersama sama menanggung resiko. Namun demikian pada tataran implementasi, bank syariah hanya menggunakan prinsip Natural Centainty Contract yaitu merupakan kontrak dalam bisnis yang memberikan kepastian pembayaran, baik dari segi jumlah (amount) maupun waktu (timing)-cash flownya bisa diprediksi dengan relatif pasti, karena sudah disepakati oleh kedua belah pihak yang bertransaksi di awal akad. Hal inilah yang mengakibatkan bank syariah kehilangan kepercayaan dari masyarakat.

Peran negara jika menginginkan peningkatan pertumbuhan ekonomi maka paradigma yang harus dibangun adalah pemberdayaan ekonomi rakyat kecil atau usaha kecil dengan demikian maka konsep pemerataan pendapatan masyarakat akan tercapai, jika pemerataan pendapatan telah terdistribusi dengan merata maka produktivitas masyarakat akan meningkat dan dengan sendirinya pertumbuhan ekonomi secara nasional akan bertumbuh.

Alquran menjelaskan bahwa rejeki itu dijamin oleh Allah sebagaimana firmannya;

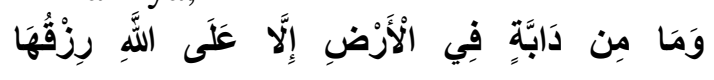

“..... dan tidak satu pun makhluk bergerak di bumi melainkan dijamin Allah rezekinya" (Surah Hud, ayat 6).

Jaminan rezeki dari Allah SWT pada mahkluk-Nya adalah jaminan yang pasti lagi benar untuk menunjukkan betapa Maha Kaya Allah yang memiliki segala sifat kebesaran-Nya.

Dari ayat tersebut diatas dapat dipahami bahwa rezeki itu juga perlu dicari sebagaimana Allah menyatakan dengan kalimat "makhluk bergerak" bukan hanya menanti yang bulat datang bergolek dan yang pipih datang melayang. Lihatlah rezeki seekor burung yang setiap hari keluar dari sarangnya dan kembali ke sarangnya dengan membawa makanan (rezeki).Kemalasan berusaha sehingga membuat periuk nasi kosong bukan karena tidak ada jaminan dari Allah tetapi karena ia yang memilih untuk itu.

Berdasarkan ayat tersebut diatas, maka bank syariah harusnya menjadi lembaga yang meletakkan visi dan misi dalam rangka menegakkan ekonomi ilahiyah dengan menggandeng para ulama sebagai pengawal aqidah dalam menyampaikan ajaran agama kepada 
umatnya baik pada wilayah nasabah juga para praktisi perbankan syariah.

Terakhir, dalam rangka mewujudkan program pemerintah yairu terciptanya pemerataan ekonomi maka komitmen pemerintah harus intens dalam mensosialisasikan kepada masyarakat luas dengan melibatkan lembaga perbankan syariah serta para ulama lokal tentang pentingnya nilai nilai ekonomi berkesadaran teologis islam melalui suatu lembaga yaitu bank syariah Peran lembaga bank syariah ini diharapkan akan menjadi penggerak dalam membumikan ekonomi ilahiyah baik pada pelaku usaha mikro maupun konglomerat dengan melibatkan lembaga formal pendidikan, ulama serta dukungan pemerintah.

\section{PENUTUP}

Bank Syariah sebagai lembaga yang keuangan Islam harus berbenah dalam rangka ikut berperan dalam meningkatkan kesejahteraan semua masyarakat. Oleh karena itu yang terbangun selama ini bahwa bank syariah hanyalah sebuah label Islam patut kita benarkan karena semangat sebagian komponen yang terkait dengan institusi tersebut bersifat tergesa gesa yang hanya berorientasi kepada pelayanan kepada masyarakat kongmelomerasi. Akibatnya, keberadaannya belum memberikan kontribusi terhadap perekonomian.

Rasionalisasi keberadaan lembaga bank syariah harus berfokus pada pemerataan kekayaan kepada seluruh masyarakat khususnya kaum miskin yang diharapkan akan memberikan kemampuan daya beli sejalan dengan konsep alquran yaitu zakat. Pemberdayaan dana zakat dalam hal ini sebagai instrumen paradigma, konsepsi dan filisofis sementara bank syariah sebagi instrumen implementatif, operasional empirik yang akan diharapkan berjalan searah menuju masyarakat yang berkesadaran ekonomi ilahiyah dalam rangka mengurai kesenjangan yang semakin melebar.

Kesadaran oleh semua unsur dalam menumbuhkembangkan lembaga keuangan syariah serta perannnya dalam pembangunan khususnya mengurai kesenjangan tersebut diperlukan kerja keras serta pemikiran yang kritis dengan meriview kembali keberadaaannya. Oleh karena itu diperlukan langkah langkah yang strategis : 1 . Peningkatan sosialisasi konsep ekonomi islam secara komprehensif yang bersumber dari Al-quran, Hadis dan Ijtihad para ulama.2. Pengembangan dan penyempurnaan institusi-institusi ekonomi syariah yang sudah ada. Memproteksi secara ketat agar transaksi yang dilakukan sesuai dengan prinsip ajaran islam, bukan hanya terjebak pada labelisasi halal tanpa ada garansi dari pihak yang berkompeten 3 . Perbaikan dan penyempurnan regulasi yang ada baik implementasi fatwa para ulama maupun regulasi pemerintah dengan melibatkan pemerintah daerah masingmasing 4. Peningkatan kualitas SDM ysng memiliki kualifikasi dan wawasan ekonomi dan keuangan syariah yang memadai sebagai ilustrasi (pada tingkat sekolah menengah menguasai kitab kuning/pesantren, strata satu (S1) masuk dibidang ilmu ekonomi dan keuangan konvensional, S2 dan S3 masuk ekonomi Islam). 


\section{Catatan Akhir :}

${ }^{1}$ http://catatankuliahfethamrin.blogspot.co.i d/2013/01/makalah-tentang-kemiskinan-dan.html

${ }^{1}$ (Triyuwono, shariate enterprise theory 2009: 393).

1 Michael P. Todaro, Pembangunan Ekonomi Di Dunia Ketiga, (Jakarta: Erlangga, 1998), h. 20

1 Chambers, Robert. 1983. Pembangunan Desa Mulai dari Belakang. LP3ES, Jakarta.

1 Sayyid Qutb, Keadilan Sosial dalam Islam, alih bahasa Afif Muhamad, (Bandung: Pustaka, 1994), cet. II, h. 40

Ihttp://chikamatematika.blogspot.co.id/

1 . John Friendman mendefinisikan kemiskinan sebagai suatu kondisi tidak terpenuhinya kebutuhan dasar (esensial) individu sebagai manusia.

${ }^{1}$ http://informasikitaall.blogspot.co.id/2013/ 05/mikro.html

1 Direktorat Jenderal Pendidikan Tinggi Departemen Pendidikan dan kebudayaan, Materi Penataran P4(JakartaDirjen Dikti Departemen Pendidikan dan Kebudayaan 1988).345

${ }^{1}$ http://www.kompasiana.com/rahmiutami9 99/bank-syariah-mampukah-mengentaskemiskinan-umat_550120f38133115318fa81ff

${ }^{1}$ Drs. M. Nur Yasin. M.Ag, Efistimologi keilmuan perbankan syariah (Malang: UIN Maliki Press 2010), 69

${ }^{1} \mathrm{http}: / /$ www.tongkronganislami.net/2012/10 /kemiskinan-dalam-perspektif-alquran.html\#ixzz3y268Y2YD

$1 \quad$ M. Jusuf Kalla, Wapres, sambutan pembukaaan Musyawarah Nasional (Munas) IV Asosiasi Bank Syariah Indonesia (Asbisindo) di Jakarta, (ANTARA News) 13 Juni 2007 17:15 WIB | 1.647 Views Rabu

\section{DAFTAR PUSTAKA}

Ali, Mohammad Daud. 1988. Sistem Ekonomi Islam Zakat dan Wakaf. Jakarta: Universitas Indonesia Press.

AM Saefuddin, Ekonomi dan Masyarakat dalam Perspektif
Islam(Jakarta: Rajawali Press, 1987), 58

Alfinn, Mely G. Tan, dan Soemardjan. 1980. Kemiskinan Struktural Suatu Bunga Rampai. Yayasan Ilmu-Ilmu Sosial, Jakarta.

Behesti, Muhammad H. 1992. Kepemilikan dalam Islam, Penerjemah: Luqman Hakim, dkk. Jakarta: Pustaka Hidayah

Chambers, Robert. 1983. Pembangunan Desa Mulai dari Belakang. LP3ES, Jakarta.

Drs. M. Nur Yasin. M.Ag, Efistimologi keilmuan perbankan syariah (Malang: UIN Maliki Press 2010), 69

John Friendman mendefinisikan kemiskinan sebagai suatu kondisi tidak terpenuhinya kebutuhan dasar (esensial) individu sebagai manusia.

Lubis, Suhrawardi K. 2004. Hukum Ekonomi Islam. Jakarta: Sinar Grafika.

Mannan, M. Abdul. 1970. Islamic Economics: Theory and Practice. dalam Delhi. Sh. M. Ashraf.

Muhammad Djakfar, Prof. Dr. H. SH.,M.Ag.(Teologi Ekonomi, UIN Maliki Press. 2010)39

M. Jusuf Kalla, Wapres, sambutan pembukaaan Musyawarah Nasional (Munas) IV Asosiasi Bank Syariah Indonesia (Asbisindo) di Jakarta, (ANTARA News) 13 Juni 2007 17:15 WIB | 1.647 Views Rabu

Pusat Pengkajian dan Pengembangan Ekonomi Islam. 2009. Ekonomi Islam. Jakarta: Rajawali Pers

Prihatna, Andi Agung. 2005. Revitalisasi Filantrofi Islam Studi Kasus Lembaga

Lewis. "Kebudayaan Kemiskinan"; Dalam Kemiskinan di Perkotaan di edit oleh Parsudi Suparlan, Jakarta - 
Sinar Harapan - Yayasan Obor 1983.

Syamsiah Badrudin, Prof. DR. M.Si, Kemiskinan Dan Kesenjangan Sosial Di Indonesia Pra Dan Pasca Runtuhnya Orde Baru, April 23, 2009

Rahmiutami/http:/www.kompasiana.com 1999/bank-syariah-mampukahmengentas-kemiskinan umat_ http://chikamatematika.blogspot.co.id http://informasikitaall.blogspot.co.id/201 3/05/mikro.html

Thamrin.blogspot.co.id/http://catatankuli ah/2013/01/makalah-tentangkemiskinan-dan.html

Destyapurwaningtyas.blogspot.co.id/http :/2010/03/tugas-makalah-sosiologitentang-masalah.html 